\title{
Frazeologija v prozi Josipa Jurčiča
}

\author{
Jurij Rojs
}

IZVLEČEK: Včlanku so obravnavani različni tipi frazeoloških struktur v prozi Josipa Jurčiča. Osrednje mesto predstavljajo glagolski frazemi. Najpogostejši so frazemi s strukturo pridevnik + samostalnik. Približno enako je tudi število religioznih frazemov. Frazeološke strukture so podane glede na besednovrstno uvrstitev sestavin.

\begin{abstract}
Phraseology in the Prose of Josip Jurčič
ABSTRACT: This article discusses various types of phraseological structures in the prose of Josip Jurčič, focusing on verbal phrasemes. Phrasemes with the structure adjective + noun are the most frequent, and there is an equal number of religious phrasemes. Phraseological structures are presented based on the part of speech of their components.
\end{abstract}

\section{Uvod}

Josip Jurčič spada med uveljavljene in plodovite slovenske pisatelje, čigar povesti, novele in romani so me vedno znova pritegovali. Pri tem me ni zanimalo samo sporočilo teh del, ampak tudi način, kako je sporočilo jezikovno oblikovano. Odločil sem se, da v Jurčičevem pisateljskem opusu frazeološko analiziram celotno Jurčičevo prozo iz različnih obdobij njegovega ustvarjalnega dela. Obravnavati slovensko avtorsko frazeologijo je težko, ker še nimamo slovenskega frazeološkega slovarja, čeprav se s slovensko frazeologijo zdaj ukvarja vse več ljudi.

Sam sem se doslej ukvarjal predvsem z rusko frazeologijo in sem ji posvetil svoj magistrski in doktorski študij na Filozofski fakulteti v Zagrebu. S historično frazeologijo sem se ukvarjal v času enoletnega stažiranja na Filološki fakulteti v S. Peterburgu. Kot izredni študent na Institutu A. S. Puškina v Moskvi sem se med drugim ukvarjal s sodobno rusko frazeologijo. Razen z rusko sem se več ukvarjal tudi s hrvaško frazeologijo. Leta 1983 sem v Novem Sadu objavil razpravo Knjižni frazeologizmi in termini v romanu Zorana ledina Mihaila A. Šolohova, tri leta pozneje pa $\mathrm{v}$ Jeziku in slovstvu analizo frazeologije Zorane ledine $\mathrm{v}$ izvirniku in slovenskem prevodu. V hrvaški reviji Filologija sem leta 1992 objavil študijo Pogled na frazeologijo M. A. Šolohova, v slovenske reviji Vestnik 1998 razpravi Avtorski frazeologizmi v delih M. A. Šolohova in Substantivna frazeologija v delih M. 
A. Šolohova. Lotil sem se tudi Puškinove frazeologije, in sicer iz romana v verzih Jevgenij Onjegin (2001). Prvo slovensko frazeološko analizo sem objavil v reviji Borec (2002) z naslovom Iz frazeološke delavnice Vladimirja Kavčiča. Kavčičevo frazeologijo sem obravnaval tudi v reviji 2000 (2006). V Zborniku Višje pravne šole v Mariboru je izšel moj prispevek Frazeološka problematika slovenskih družbenopolitičnih besednih zvez v ruskem jeziku. Leta 1985 sem se udeležil Mednarodnega simpozija Poetika v ustvarjanju M. A. Šolohova, na katerem sem sodeloval z referatom Frazeologičeskie svojstva personažej Podnjatoj celini M. A. Šolohova. V soavtorstvu z akademikinjo Antico Menac sva izdala Hrvatsko-slovenski frazeološki rječnik, Zagreb 1992.

Celotno frazeologijo v delih M. A. Šolohova sem obdelal v doktorski disertaciji (Zagreb 1995). Štirinajstkrat sem predstavil starejše in sodobne ruske pisatelje na Radiu Slovenija. Vzporedno z rusko frazeologijo se ukvarjam tudi s terminologijo. V tipkopisu imam slovar terminov iz jugoslovanske družbene prakse. Slovar ni izšel zato, ker je nastal nov družbeni red. Na VIII. Mednarodnem slavističnem kongresu Zagreb-Ljubljana (1978) sem imel referat $O$ samoupravnih terminih. Prevedel sem tri ruske romane (Ju. V. Bondarev, Žareči sneg, Ljubljana 1984; B. L. Vasiljev, A zarje so tako tihe in A. I. Solženicin, Rusija v razsulu, Ljubljana 2000), komedijo V. Rozova, Štiri kaplje (Celje 1976) ter 24 ruskih novel in štiri pravljice.

Leta 2003 je Janez Keber izdal Frazeološki slovar slovenskega jezika-Poskusni zvezek. Slovar ima okrog 160 besednih gnezd z navedbo frazemov. V uvodu FS navaja, kaj mu pomeni frazem: »Frazemi so stalne besedne zveze, katerih pomen ni ali je samo delno ugotovljiv iz pomenov njihovih sestavin, ki imajo praviloma stalno in samo omejeno spremenljivo sestavo« (FS, str. 6). Enakega mišljenja sem tudi sam.

Omeniti velja, da so pogledi na pojmovanje frazemov zelo različni. Sam se v svoji raziskavi najbolj opiram na zagrebško frazeološko šolo, katere utemeljiteljica je akademikinja Antica Menac. Le-ta določa minimalno FE »fonetično besedo«, to je eno samostojno naglašeno besedo, na katero se naslanjajo enklitike ali proklitike (za dlaku, milo mi je...)«. ${ }^{1}$ N. M. Šanskij ${ }^{2}$, N. M. Babkin ${ }^{3}$, V. P. Žukov idr. trdijo, da je treba upoštevati biakcentnost pri določevanju FE. L. I. Rojzenzon ${ }^{5}$, A. Menac ${ }^{6}$, M. Popović 7 J. Keber in podpisani določamo, da je frazem besedna zveza, ki ima najmanj dve besedi, od katerih je ena naglašena. Za frazem navajam tudi kratico TBZ (trdna besedna zveza, nem. die feste Wortverbindung, rus. USK: ustojčivyj

1 Antica Menac, Neka pitanja u vezi s klasifikacijom frazeologije, Filologija, št. 8, Zagreb 1978, str. 221.

2 N. M. Šanskij, Frazeologija sovremennogo russkogo jazyka, Izd-vo Vysšaja škola, Moskva 1969, Izdanie 2-e, ispravlennoe i dopolnennoe.

3 A. M. Babkin, Russkaja frazeologija, ee razvitie i istočniki, Leningrad 1970.

4 V. P. Žukov, Semantika frazeologičeskih oborotov, Moskva »Prosveščenie«, 1978.

5 L. I. Rojzenzon, Lekcii po obščej i russkoj frazeologii, Učebnoe posobie, Samarkand 1973.

6 Antica Menac, Hrvatska frazeologija, Knjigra, Zagreb, svibanj, 2007.

7 Iz frazeološke problematike, Milenko Popović: O frazemu i zamenljivosti njegovih elemenata, Zagreb 1980, str. 48. 
slovesnyj kompleks), za prosto, tj. nefrazemsko, besedno zvezo uporabljam kratico PBZ (nem. die freie Wortverbindung). V slovenskih frazeoloških študijah se za frazem uporablja tudi izraz UBZ (ustaljena besedna zveza).

Frazemi se v procesu govora vzpostavljajo kot že narejene BZ (besedne zveze) $\mathrm{s}$ stalno strukturo in semantiko. Na podlagi takega pojmovanja frazema je narejeno več frazeoloških slovarjev. Omenimo le Frazeologičeskij slovar' russkogo jazyka v redakciji A. I. Molotkova ${ }^{8}$, Moskva 1967, Russko-horvatskij ili serbskij frazeologičeskij slovar' pod redakciej Anticy Menac ${ }^{9}$, Hrvatski frazeološki rječnik, Zagreb 2003 avtorjev A. Menac, Ž. Fink-Arsovski in R. Venturina. Ne moremo prezreti hrvaškega frazeologa Josipa Matešića, ki je s sodelavci izdal Frazeološki rječnik hrvatskoga ili srpskog jezika, Zagreb 1982. Posebej je vreden naše pozornosti, ker ima več kot 30000 gesel. Minimalna FE je po njem sestavljena iz najmanj dveh polnoznačnih (avtosemantičnih) besed.

Pri analizi Jurčičeve frazeologije v prozi sem izhajal iz lastnega razumevanja frazeologije. Največ sem si pomagal s Slovarjem slovenskega knjižnega jezika (Ljubljana 1970-1991) in s slovarskim delom Slovenskega pravopisa 2001. Zelo mi je bil v pomoč tudi v Slovensko-nemški slovar M. Pleteršnika. En Jurčičev frazem (hočeš nočeš) mi je pomagal določiti akad. J. Toporišič (11/X-2007), za kar se mu zahvaljujem, zahvaliti pa se moram Univerzitetni knjižnici v Mariboru, ki mi je za dalj časa posodila Zbrane spise Josipa Jurčiča.

$\mathrm{K}$ avtorski frazeologiji prištevam tudi pregovore in reke, znane citate, krilatice, kalambure, narodne uganke, reminiscence, substitucijo, elipso in epiteton, nanašajoč se na jedrno besedo. Jurčičevo frazeologijo določam največ iz lastnega poznavanja splošne frazeologije, zlasti ruske, ki sem jo preučeval v okviru magistrskega in doktorskega študija. V Jurčičevi prozi je največ UBZ s samostalniško jedrno besedo, sledi glagolska z različnimi besednovrstnimi komponentami. V magistrskem delu prve poimenujem imenske (samostalnik + samostalnik, samostalnik + glagol, samostalnik + glagol + samostalnik, samostalnik + glagol + pridevnik...), ki so skupaj z glagolskimi najpogostejši v Jurčičevi prozi. Bogato je število religioznih frazemov (upoštevati je treba čas, $v$ katerem je pisatelj ustvarjal), pregovorov in rekov ter tavtoloških frazeoshem (Šmelev, Leonidova, Menac) ${ }^{10}$. V nadaljevanju navajam različne strukturne tipe imenskih frazemov:

Samostalnik + samostalnik

»cvet prebivalcev«/GR, 317/, »v cvetu svoje mladosti«/SKC, 296/, »viharjev ljubezni«/DZ, 404/, »mati priroda«/CS, 130/, »Slave sinovi«/KPS, 95/...

Samostalnik + glagol

»besedo držati« /CS, 184/, »besedo prelomil«/DZ, 313/, »desnica daje«/CS,

8 Frazeologičeskij slovar ' russkogo jazyka pod redakciej A. I. Molotkova, Moskva 1967.

9 Russko-horvatskij ili serbskij frazeologičeskij slovar' pod redakciej Anticy Menac, Zagreb 1979-2980 (Me).

${ }^{10}$ Etbin Bojc, Pregovori in reki na Slovenskem, DZS, Ljubljana 1980. Antica Menac, Hrvatska frazeologija, Knjigra, svibanj, 2007, str. 42. 
45/, »...so si jako glave belili« /DB, 117/, »...marsikoga, ki hlače nosi« /PVNSP, 130/, »...pa so se hlače še bolj tresle«/PVNSP, 128/, »hudič bi ga sedaj prinesel« /DZ, 311/, »da bi jezik brusili«/CS, 26/, »jezike brusijo«/KŽ, 18/, »da bi se jeziki otajali«/DB, 277/, »...da se bo jezik bolj razvozljal«/BT, 197/. »Pol nas bo pocepalo po polju in iztegnilo kopeti...«/JK, s. j., 119/ - vulg. , »... meščanska kri ti vre po žilah...«/DB, 200/, »kri mu zavre«/JKo, 234/, -enako KŽ, 31/, »...morda ti lasje vstanejo...«/JKo, 206/. »Torej vas luna trka?»/T, 104/.»...vrat mu zavij, če ga luna ne trka«/KŽ, 54/.»Spusti se v tek..., kar ga neso noge«/PT, 56/. »... kaj moraš povsod nos vtikati?»/JNMSP, 215/. »...oblačica se nabira...«/T, 145/. »Leto oseminštirideseto nam je oči odprlo«/ČIŽ̌PA, 225/. »...oko starega Bitiča (je) obtičalo...«/TP, 145/. »...pamet je izgubil...«/PT, 60/. »... zopet ga bo pamet srečala!«/BT, 202/. »Da bi te pamet srečala!«/NKU, 282/.«...da bi ga pes oblajal...« /DB, 116/.»... nisi vreden, da bi te pes povohal«/SS, 340/. »...podpihovalci so pete odnesli...«/R, 15/, enako SSS, 12/. Notranja frazeologizacija je v primeru: »Pravdo so pravdali«/DZ, 300/. »Solnce je pripekalo...«/GR, 325/- enako v VVK, 110 in 111/. »...prijatelja nimam, da bi mu mogel srce odpreti«/BST, 175/. »...tempora mutantur «/DB, 137/. »...moramo iti tlako delat...«/HMS, 30/. »... ji je um malo zablodil «/KŽ, 34/. »Vest ga je pekla«/DB, 153 in KŽ, 33, 33/. »Jaz ti bom vetra dal«/R, 55/. » »Vodo jima še skalim«/GR, 346, 346/.

Samostalnik + glagol + samostalnik

»Beseda da besedo« /D, 433/. »...vino je razvezalo jezike...«/IET, 165/. »... smrt je imela bogato košnjo«/J K, s. j.,332/. » da bi uma ne izgubila«/LV, 68/. »Tvoja ura se je iztekla...«/D, 442/. »... zopet uši pasti«/SSS, 28/. »Tako me včasih vest peče...«/DIZ, 153/.»Vino pellite curas«/DB, 137 (Horacij).

Samostalnik + glagol + pridevnik

»Ali njega obraz je bil še vedno kisel...«/TP, 131/.

Samostalnik + glagol + predlog + samostalnik

»...gradove zidati $v$ oblake«/DZ, 382/. »...beseda mu je ostala $v$ grlu«/BT, 195/- enaka UBZ je v DB, 360 in v romanu CS, 77. »... ogenj je švigal vsakemu iz oči« /JK, s. j., 321/.»...prostost je šla po vodi«/SSS, 32/.«...sem bil prste poteknil $v$ to mešanico.../JK, s. j., 312/. »Solze so mi prišle $v$ oči... «/NV, 128/. »Solze se ji udero po lici«/CS, 137/. »Kamen mu leži na srci«/CS, 77 in 84/. »Kamen se je odvalil od srca« /MP, 80/, enako v SKC, 294/. »Stvar je že v tiru...«/DZ, 410/. »Vino stopa $v$ glavo...«/SSS, 30/. »...malo besedi je šlo čez zobe«/D, 357/.

Samostalnik + glagol + predlog + pridevnik + samostalnik »...življenje je $v$ božjih rokah...«/LV, 24/.

Samostalnik + predlog +samostalnik + glagol

»...pak je stric Blaž, ko je bil sam, usta na šir odprl...«/R, 48/. »...klin s klinom, skrb s skrbjo izbiti«/LP, 54/. »...sproti bi pa fige $v$ žep vteknil «/VSŽ, 296/. »Komaj sem jezik za zobe dejal«/DB, 225/. 
Samostalnik + predlog + samostalnik

»Vse prošnje matere so bile bob $v$ steno« /D, 410/, enako T, 156/. »...dan na dan«/KŽ, 14, 67, UB, 188, G, 13, DB, 136, KSVVG, 212, BT, 185, PT, 42, IET, 188, PB, 194, CS, 61/. »Glavo za glavo...Glavo za glavo«/SKC, 254, 297, DB, 396, LV, 114/. UBZ spominja na biblijski rek: oko za oko, zob za zob. Torej: glavo za glavo, zob za zob«/DZ, 396/. »...leto za letom«/JK, s.j.,224/. »To je bilo olje $v$ ogenj«/PT, 49/. »...pot pod noge« / CS, 247/. »...srce na jezik «/BST, 171/.

Samostalnik + veznik + samostalnik

».. .leto in dan «/SND, 135/, enako PT, 188, 219, KSVVK, 210, DB, 338, VVK, 103 in DZ, 365/. »...noč in dan «/DB, 153, SS, 406, CS, 234 in LV, 53/. »...petek ali svetek«/SSS, 38/, T, 92/.

Pridevnik + samostalnik

Teh frazemov je največ. Razvrščam jih po abecednem redu jedrne besede: »Zini nam še eno..., da bosta dve modri besedi«/HMS, 79/. »... niste rekli žal besede« /SS, 377/.»...včasih sva bila vinska brata «/R, 46/. »...Ribničan, zvita buča...«/SND, $116, » /$ «...dolg čas »/CS, 55, 67/.»...kratek čas »/IET, 174, KŽ, 6, LV, 15, HMS, 42 in KŽ, 15/. »...v prejšnjem in ondanjem času «/GR,326/. »Šele v poslednji čas »/ČIŽPA, 234/. » ....stari časi«/IET, 188/. »Vi ste dober človek in dobrega človeka sem zmerom vesel«/CS, 162/. »...živ človek...«/B I L, 231, D, 358/. »...bridko čustvo...«/L, 21/. »Krjavelj ves tisti božji dan ni nič dobrega povedal«/DB, 231/. »...veliko bridkih dni«/JK, s. j., 296/. »...žalosten jesenski dan«/SS, 310/. »...ob pasjih dnevih «/R, 44/45/, enak frazem še je v VSŽ, 282. »...lep poletenski dan« /VVK, 110/. »Poletnega dne je bilo, na tržni dan«/BT, 173/. »bodo sodnemu dnevu zvonili...«/CS,213/. »...po toplem dnevu na večerni hlad...«/DB, 308/. «...bil je najlepši zimski dan... «/DB, 210/. »...živ dan...«/DB, 173/. »Vino je božji dar« /DB, 156/. »... ne zatrl dušnih darov«/G, 17/. »...ta debeli denar...«/SSS, 7/. »... pojdeš v krtovo deželo«/R, 41, T, 153, KŽ, 88, JK, s. j., 223/. »...prozaične kramarske duše tega suhega sveta /L, 13/. Jedrna beseda duša ima še komponente pasja /JKo,194, T, 163/, poštena /SKC, 243/in živa /R, 66, 73, D, 414, JK, s. j., 248, G, 3, DB, 195/196, LP, 74, SKC, 266, DIP, 82, POSG, 50,CS, 22 in D, 398. «...ta bo dal pasjo figo...«/KŽ, 62/. »...s povešeno glavo...«/PV, 171/. »Poleg prebrisane glave, ostrega pogleda...«/KŽ, 8/. »...raztrgana Višnja gora«/SND, 112/. »lepo plavolaso gospodično...«/DZ, 289/. »Sinoči je prinesel ves kitast hrbet domov« /ZVGIRŽ, 114/. »Polona je zapisana hudiču« /PV, 169/. »...sveta jezica ...«/DB, 313/. Jedrna beseda jezik ima komponente gladek /CS, 77, HMS,41, KZ̆, 42/, dolg /CS, 26/, pošten/HMS, 43/in zavezan /KŽ, 70/. »kaplja« ima komponenti sladka /DB, 143/144/ in zlata/CS, 110/111/. »... suh kašelj «/L, 18/.»...važen korak«/ZŽ, 257/. »...čisto stare korenine...«/DB, 141/. Jedrna beseda koža ima dve komponenti človeška/JK, s. j./275/ in stara/JNMSP, 203/ in JK, s. j., 210/. »kri je lahko mirna «/MIP, 69/, vroča in nagla /T, 103, 138/. »...v nebovpijoča krivica«/JKo, 238/. »živ krst«/SKC, 251 in JKo /220/. »...bridki kruh ...«/DZ, 327/. »lasje« so lahko kodrasti, črni /SS, 324, CS, 180, ČIŽPA, 228 , HMS, 41, rjavi /SKC, 292/, rmeni /CS, 69/70, 145/, rumeni /DB, 125, IET, 163 / in sivi /DZ, 351, BT, 186, SSS, 65 in 
GR, 334/.»...od nesrečne ljubezni...«/DZ, 421/.»...polna luna...«/UIB, 180/.»... prazne marnje...«/G, 5/.»...belih menihov...«/SSS, 19/.»...hudih muh...«/L, 20/. »... hudobnih muh ...«/L, 11/.»Saj babe imate nos tudi dober...«/SS, 353/.»obraz« je lahko čemeren, kisel /TP, 135/, DZ, 15/ in resen /PT, 45/. »oči« so najpogosteje črne /HMS, 36, CS, 49, 66, D, 356, DB, 106, J Ko, 224, JK, s.j.228/, lahko so modre /DB, 121/, plave /BT, 174, KŽ, 26, IET/, sive/IET, 198/, svetle /DB, 115/, temne /KŽ, 85/, zardele /SS, 339/340/in žive /R, 26, GR, 320/. »pamet« je lahko kratka /DB, 178/, zdrava /JKo, 223, KZ̆, 79, DB,198, 260, PB, 208/ in zmešana /UIB, 178/. »...težke pete《/SS, 315/.»...pri belem poldnevu«/L, 17/.»...za...dušnega pastirja...«/DV, 257/. »...kurja polt«/JK, s. j., 308/. »...polža priklenjenega«/SND, 110/. »...smrtno popotnico »/DB, 243/244/. »... na smrtni postelji«/DB, 364, 391, 399/. "resnica《 je lahko gola /TP, 146, DB, 241/ in živa /R, 57/58/. »...izgubljena reva" /UB, 193/. »... s praznimi rokami...«/IET, 194/. »Pa to je bila prazna skrb...« /SSS, 75/. »...bela smrt ...«/LV, 33/. »...zmrzli skorjasti sneg«/D, 366/. »solza« je lahko debela /DB, 168, 227, G, 15, D, 378, PT, 155/156 / in vroča /DB, 415/. »srce« je lahko blago /DB, 275/, dobro /CS, 32, T, 155/156, DB, 240, 345, 406; HMS, 44, POSG, 49, DZ, 324/ in trdo /PB, 210/. »Toliko denarja v cesarskem srebru...«/R, 56/. »...čemeren starec...«/DP, 263/.»... napeti bi moral zadnje strune...«/DZ, 374/. »svet« je lahko božji /SND, 139, JK, s. j., 313/, širni /BR, BD, 267/ in vesoljni /DB, 336/. »...po novejši šegi...«/CS, 145/. »...šleva šlevasta ...«/NPIP, 78/. »...zlatega teleta...«/NPIP, 102/. »...smrtni udarec...«/R, 50/. »um《 je lahko bister /DB,108/ in zdrav /CS, 192/. »ura« je pri Jurčiču poslednja /SSS, 21/22, 39, DB, 312/, smrtna /KŽ, 76/ in zadnja /KJKPPD, 247/. »...iz srednjega veka... «/NPIP, 105/. »volja« je lahko božja /JKo, 240/, dobra /D, 455/ in židana /NPIP, 74/. »...rešilna vrv « /IET, 229/. »... v svetem zakonu«/KŽ, 81/. »...poglavitno zrno...«/KŽ, 83/. »... črna živina«/ČIŽPA, 229/.

Glagol + samostalnik

»...sem držal besedo《/DZ, 347/. »...lehko mu teče beseda...«/VSŽ, 297/.»... ne bom zaslužil nobenega bora...«/SSS, 5/. »...nisem dobil ne boriča od doma« /SSS, 61/. »...je bil duša vsega dela«/IET, 178/. »...vsakemu (se) razveže jezik «/CS, 149/. »...bi si zavoljo njega belil glavo«/DB, 237, TP, 138, SND, 117, OBKINH, 62/. »...si ubijajo glave...« SND, 117/118/. »Nemci ne iztegnejo gobca za nas«/ČIŽPA, 288/-vulg. V naslednjem stavku imamo tri frazeme: »Zdaj me je le izpreletela groza, lasje so mi vstajali, mravljinci so leteli po hrbtu...«/SND, 123/. »Uči se brzdati svoj jezik...«/GR, 322/. »A kdo mu je iztegnil jezik...«/D, 359/. »...da bi se malo ohrabril in si omajal jezik...«/HMS, 35/. Frazeološki zraslek je frazem: »Pobral bom svoja kopita, majhna in velika«/KŽ, 13/. Jedrna beseda kri ima dve glagolski komponenti: »...da bi si ohladil kri«/KŽ, 40, T, 136/137/. »Vrela jim je kri...«/NS, 293, D, 379/. »...tedaj mu je zavrela kri«/D, 419/. Kdaj si mi kruha rezal?«/T, 103/. »...kdor bi si upal skriviti las...«/JKo, 225/. »...za njo bi bil delal most «/L, 9/.»...me je izpreletel mraz«/D, 373/. »Zato me pritiska nadloga...«/ON, 56/. »...so zatirali in žulili narod ...«/OAA, 89/. »Le delaj se norca iz mene!«/CS, 156/. »...hočejo povsod vtikati nos...«/TP, 134/. »...Pavel Slamnik (je) obrnil oči...«/PT, 43/. »Žena (je) odprte oči imela...«/R, 35/. »Gospod bi bil 
odnesel pete«/NV, 114/.»...je pobral pete...«/SSS, 10, CS, 134/.»...kadar pete stegneš...«/R, 25/ - vulg. »... je imel piko nanj...«/HMS, 90/. »... ne bo odslej nikdar več raznašala pošt«/PV, 156/. »Vsak, kdor je kupoval kak rep v hlev...«/T, 103/. »France...se ni dal pregovoriti, da bi prestopil tudi on Rubikon »/R, 68/- knjiž. ekspr. »Pela je sekira ...«/JK,s.j. 352/. »...mu ni bilo noben sile...«/JK, s. j. 226/. »...če vrag ne skali vode« /KŽ, 21/. »...in se mi še zdaj cede sline «/NPIP, 77/. »... je našel kruto smrt «/NPIP, 87/. »Ravno je prav gorko sijalo solnce...«/DB, 210/. »Deklico zalijejo solze...«/HMS, 47/. »...Riblju (se je) razkipelo sovraštvo...« /IET, 228/. »...(sin) mi dela sramoto...«/UB, 192/. »Ni bilo treba iskati strehe...« /G, 23/. »...naj se svet podere« /NV, 137/. »... (rokovnjači) so bili od nekdaj grozna šiba kmetu in gospodu«/R,15/16/. »Eden najlepših večerov je razgrnil svojo poletno tišino črez dol in goro«/IET, 173/. »...tlačim božjo travo«/JNMSP, 203, DB, 150, D, 410/. »...drugega jima ni kazalo, kakor da gresta po svetu s trebuhom za kruhom«/ON, 54/. »Dejali so, da ga je udarilo božje«/D, 461/. »...lačen, žejen, bos, raztrgan (je) uši pasel po svetu...«/ON, 56/. »...starca (je) pekla vest...«/GR, 342/343/. »Vsak je napel poslednje žile...»/JK, s. j.,132 /.

Glagol + samostalnik + predlog + samostalnik

»...odkar je nehal rasti bob $v$ klasju«/DB, 144/. »Kolikokrat si že imel v bitvi glavo bolj na vagi«/IET, 179/. »...je imel skrbi črez glavo«/DB, 152/. »...je bila beseda na goltancu« /PV, 163, VSŽ, 286/. »...veselo (sta) zidala gradove v oblake« /PV, 163/. »...vidva bosta držala jezik za zobmi«/KŽ, 54, JK, s. j.,269/. »Imela je že ostro besedo na jeziku...«/L, 20/. »...ravno mene ne puste jeziki pri miru«/D, 358/. »...ima pravico na jeziku« /GR, 364/365/. »... si ni hotel nakopavati križa na glavo...«/NV, 114/. »...kaj je gnalo kri v lica...«/GR, 324/. »...dobil je mačka $v$ vreči...»/DB, 152/. »...to vam je dalo nekaj muh v glavo«/DB, 261/. »...zmotal je vse niti z motovila«/PV, 163/. »...nisem eden tistih, ki imajo jok za rokavom, mi prihajajo solze $v$ oči $/ \mathrm{NV}, 114 /$. »Odvalil se mu je drugi kamen od srca...« /PT, 44, JK, s. j., 253/. »...treba je bilo ozdraviti se, zbijati klin s klinom« /CS, 38, KJKPPD, 236/. »Kar bi bil rekel, bi bilo olje $v$ ogenj«/LV, 101/. »...dasi mu je bilo gledati smrti $v$ oči«/JK, s. j., 253/. »...je bil trn v peti...«/KSVVG, 212/. »...zato počasi napelje voz na svoje kolesnice...«/CS, 91/. »Ravno to je staremu bolj gnalo žolč $v$ kri« /GR, 322/.

Glagol +samostalnik + veznik + samostalnik

»...je imel mnogo preglavic in križev...«/KSVVG, 218/. »...tako je tudi ona imela svoje križe in težave«/D, 356/. »...jezik, v katerem vam zdaj razkladam svoje križe in težave«/SSS, 14/. »(tožba), ki bo trajala leto in dan«/T, 141/. »Mladeniču je gorelo oko in lice«/BST, 174/. »...dan na dan (so) bolj hladili srd in togoto na sovražnika«/GR, 372/. »Žolnir je bil pobral šila in kopita...«/KŽ, 72/.

Glagol + pridevnik + samostalnik

»Kdo ne bi...na okno naslonivši ...ne oddehnil dolgega časa!«/BT, 188/189/. »(vaju) je...obsedel hudi duh«/T, 96/. »...če boš zinil živi duši...«/KSKC, 241/. »Občine so...imele svoje velike križe...«/R, 15/. »...loviti slepe miši«/NV, 118/. 
»...imam tak dober nos«/R, 20, HMS, 82/. »...zbirate žareče oglje na grešno glavo«/DZ, 377/. »... hlapci so delali kosmate opombe...«/TP, 145/. »Mrzel pot ji oblije hrbet...«/HMS, 85/. »Sova je potil mrzel pot«/D, 441/.»...oblije ga mrzel pot«/SKC, 295/. »Gospodarstvo je šlo naglo rakovo pot«/UIB, 191/. »(Francozi) so bili dobre volje«/SSS, 22/.

Glagol + glagol + glagol

»...hočeš nočeš moraš« /pogojni frazem/SND, 109/110/. »...jaz mu pokažem spat«/SND, 123/.»...da so me tako polomili, potrli, potepli, nabili in premikastili, da ne bom živ dan belega pljunka pljuval iz ust«/T; 169/. »Pojdi se solit...«/R, 65/.

Glagol + predlog + samostalnik

$» \mathrm{Ne}$ izpotikaj se ob malo besedo...«/JK, s. j., 314, HMS, 31/. »ne gre mi $v$ betico...«/D, 436/. »... ako mu Domen stopi na brado in čeljusti...«/D, 444/.»Vsa njegova hudobija je prišla na dan«/JK, s. j., 350/. »...očital sem ji vse, znesel vse male reči na dan «/NV, 128/. »Torej je Pavel tudi ženitev preštudiral do dna«/PT, 42/. »...da ga bodo kmalu prijeli ljudje pri duši«/T, 128/. »...bo delal z glavo...« /DB, 105 /. »...izbij si iz glave«/JKo, 227/. »...vse te skrbi (jim je) nakopal na glavo«/SND,117, D, 423/. »...odgovori ded in kinknejo z glavo...«/SND, 143/.»Kaj ti ne trešči v glavo, hlapče!«/D, 362/. »...vendar je zmajal z glavo«/GR, 354/. »...te poznam $v$ globino...«/GR, 324/. »Ti pa poženeš vse po grlu...«/D, 396/.»...kar mu je bilo na jeziku «/L, 34/35/. »Eno reč sem imel že dostikrat na jeziku«/D, 448/. »... vsakemu je ostalo vprašanje na jeziku«/JK, s. j., 259/. »...molče (sta) izpila vino do kaplje«/GR, 327/. »...povedi, kar ti je padlo $v$ koš«/VSŽ, 293/. »...mu pride vse $v$ koš«/DB, 135/. »...možje ne pridejo do kože...«/SS, 317, JK, s. j., 309/. »Jaz sem ga prosila, za križe in težave sem ga prosila...«/DP, 273/. »... ljudje si precej silijo $v$ lase...«/SSS, 77/. »Drugo muho sem ujel na limanice«/JK.s. j., 271/.»Vrag vedi, jaz sem ga pustil pri miru«/D, 364/. »Kaj ti pride na misel!«/DB, 238, SSS, 18, SS, 397/. »...hudodelstvo je že vpilo $v$ nebo...«/JK, s. j., 273/. »...kdo je živ, kdo umrl, kdo obogatel, kdo prišel na nič...«/L, 32/.»...brž je dal...sklicati na noge...» /GR, 385/. »...spravil na noge«/CS, 141/. »...obriši se gospoda pod nosom...« /JNMSP, 211/. »...te je tako vodila za nos«/NV, 138/. »...vodil jo je za nos«/CS, 217, T, 140, D, 405; z dovršno glagolsko komponento je FE: »...zvodila za nos«/ $\mathrm{NV}, 113,129,129 /$. »...je še nekaj časa lovil z očmi«/DB, 133/. »To mu je padlo $v$ oči...«/DZ, 438/. »...je spremljala jezdeca z očmi«/HMS, 44/. »...je...spravila pod palec vsakega«/KŽ, 8/. »...vas imam vse okoli pod palcem «/CS, 47/. »Ožbe...(je) delal največ po svoji pameti«/JK, s. j., 247/. »Dobila ga je čisto $v$ pest«/DB, 152/. »...bomo Lovretu za petami«/DB, 140, SKC, 301/. »... stopiti mestu malo na rep« /HMS, 62/. »...pa mu ne gre nikjer po robu«/VSŽ, 291/. »...vse sem dal iz rok« /JNMSP, 217, CS, 64/. »...ni šlo od rok «/PB, 214, SS, 325/. »...se gotovo zvrže po očetu«/L, 29/. »...imel na rovašu...«/IET, 213/. »...lahko bi sedela $v$ senci«/SS, 321/. »...govore, da je zbolela na smrt« /MP, 84/. »Pridiga...ni segala do srca« /CS, 86/. Jedrna beseda »srce« ima še glagolske komponente delati, imeti, povedati, biti, gledati, videti, vsaditi... »(Novice) so nosile na uho«/DB, 382/383/. »... eden dovtipnežev (je) udaril na to struno«/PT, 49/.»...mogočno habsburško dr- 
žavo (bi bil) vrgel iz starih tečajev«/IET, 152/. » je sedel na tilniku«/OAA, 87/. »Kako ti je to prišlo na pamet?«/IET, 180/. »Otroče je bilo...z uma...«/GR, 366, JKo, 220, D, 442, JK, s. j., 292, JKo, 190/191/.»... .ali sta že iz uma...«/SND, PVNSP, 121, SSS, 63/. »...meni ni nikogar treba, da bi mi gostolel na ušesa«/CS, 29/. »Vleče na ušesa...«/R, 50/. »...sem si že zapisal za ušesa...«/KŽ, 55/. »...imam (Petra) na vajetih...«/JK, s. j., 271/. »...izpolnitev je splavala po vodi«/DB,379/. »...cigan (ga) lehko pesti po volji «/JK, s. j., 273, JNMSP, 217/. »...naklicati si na vrat...«/KJKPPD, 237/. »...naložiti si na vrat...«/L, 3/. »Pridem ti že do zoba« /JK, s. j., 290/. »...babe te ne bodo vlekle črez škrbaste zobe«/DP, 268, JNMSP in L, 4/. »Tega imam jaz $v$ želodcu«/DB, 265/.

Glagol + zaimek + samostalnik

»...se zopet smeje na vsa usta«/DB, 115/. »...odpri mi svojo dušo...«/LV, 63/. »Vlekel je na vse duške«/VSŽ, 281/. »...živel (je) čisto po svoji volji«/DB, 175/. »Bal se je pa bolj za svojo kožo«/T, 128/. »...joka na vse pretege...«/LV, 31/- ekspr. »In v to Mari se je bil Lipe zaljubil z vsem srcem in z vso dušo«/L, 6/.

Zaimek + samostalnik

»...njega dni je bilo«/ZVGIRŽ, 109/. »...meni nič tebi nič«/DB, 361, HMS, 45, DZ, 338, CS, 47, SND, 126, D, 370/. »...svoj čas«/PB, 188/. »...svoje dni«/DB, 137, SND, 147/.

Zaimek + glagol

»...se sme kakova zasoliti«/VSŽ, 296/ - zast. » Ali kar je, to je...«/TP, 130, DZ, 339/. »Kar je, pa je«/CS, 155, DB, 154/. »Pa kdor nima, ta nima«/POSG, 45/. »To je, kar je!«/KŽ, 68/.

\section{Prislov+samostalnik}

»Krčmar da...zapreti v temno ječo...«/POSG, 45/. »To je pa že žaltavo maslo«/SS, 318/. »...je imel zdaj še drugo črno misel«/SKC, 288/. »Srpo upira pogled«/G, 22/. »...kako bi zapodil bridko smrt...«/JNMSP, 209/. »...križem sveta《 /OBKINH, 58, POSG,47, 49; JK, s. j., 279/. »...zdaj boš pa smrtno uro sam umiral« /JNMSP, 209/.

\section{Prislov + glagol}

»...in čudom se je ženska čudila...«/KŽ, 14/-hist. Enaka FE je v LV, 43 in TP, 142/. »... in se kislo drží«/SND, 139/. »Z odprtimi usti (je) debelo gledal«/HMS, 86, SND, 138, MP, 71, CS, 192, DB, 109, 363 in R, 55/. »...pisano pogleda «/POSG, 44, SSS, 12 in JNMSP, 212/. »...srdovito gleda «/HMS, 39/. »...srpo gledal«/DB, 313/. »...srepo gledal«/PV, 166/167/. »...debelo hrkal...«/HMS, 50/. »...visoko letal...» /DB, 205/.»...norca se delaj...«/BT, 198, DB, 203/.»...postrani pogledavši...«/D, 395/. »... ni rekel belo, ni rekel črno...«/R, 219/. »(luna) je tiho sijala...«/T, 139/. » ...je vznak ležal človek...«/SKC, 309/. 
Predlog + pridevnik + samostalnik

»Zakaj bi potlej na stare dni toliko trpel...«/LV, 33/. »...do zadnjega diha« /HMS, 33/.»...v božjem imenu...«/CS, 181, LV, 25, 43, R, 52/.»...od mladih kolen...« /SS, 20/. » na širokem svetu...«/DB, 325/.»...na široki zemlji...«/R, 58/59/.

Predlog + samostalnik + glagol

Jedrna beseda "glava" ima ob sebi glagolske komponente: izbiti /SKC, 251/, postaviti /T, 91, SS, 380/ in primuzati /G, 6/, obenem pa predloge: iz, na, z, v. »po grlu pognati...«/T, 9/. »... na jezik pride...«/DB, 274/. »Na jeziku mu je bilo...« /CS, 188/.»...na jeziku nosila...«/BR, BD, 273/.»...in mu je za vselej strupeni jezik zavezal...«/R, 28/. »Iz kože poskoči od jeze«/R, 55, JNMSP, 212/. V križ mu je /hodilo...«/PT, 42/.»V lase si skočite...«/JNMSP, 203/. »...ko bi jo z lučjo iskal« /OBKINH, 58/59/. »Na misel ni prišlo...«/KSVVG, 209/. ».. .je šlo za nohte«/PV, 152/. »...me je potem še za nos vodila...«/BR, BD, 274, SS, 385, IET, 251, LV, 99, T, 96 in DZ, 396/. »...se z obraza bere...«/DB, 123/. »Dokler je bil on, se ni nikomur v mestu drezalo $v$ oči, da bi on ne bil stopil na noge «/HMS, 82/. »...preveč $v$ oči mahajo...«/SS, 335/. »...se je kaj črez ojnice govorilo«/ČIŽPA, 229/. »... da po pravici povem...«/NV, 113/.»...ljudje (bodo)...s prstom kazali...«/T, 96/. »...se jima malo po robu staviš«/DB, 284/. »...ko bi jo na kolenih prosil«/KŽ, 80/. »...da bi...pod travo prišli «/LV, 65/. »...potlej me $v$ uho piši...«/R, 66/. »... na uho je vleklo skrivnostno šepetanje«/BST, 183/. »... ali na um mi ni prišlo...« /DP, 265, HMS, 55/. »...na ušesa vlekel«/DZ, 359/. »...ni šlo po volji...«/UB, 189/. »...na vrat obesili...«/LV, 63/. »...da bi se $v$ zemljo udrla...«/CS, 155/. »...tebe nosijo po zobeh ...«/SS, 364, 368/.»Sosede so črez zobe vlekle...«/DB, 221/.»...v zobe se mu (je) zasmejal...«/NV, 126/127/.

Predlog + samostalnik + predlog + samostalnik

»...od jutra do večera...«/KŽ, 52/53/.»...od kraja do konca...«/PVNSP, 128, JNMSP, 211 in L, 5/. »od pete do glave...«/JK, s. j., 233 in $\mathrm{D}, 442 / . » . . . v$ rodu po krvi...«/DB, 152/.»...od nog do glave...«/DB, 128, HMS, 30/.»...od pete do tal...«/T, 101/.»...od svita do mraka...«/KŽ, 95, DP, 263/. »..od zore do mra$k a \ldots \ll / \mathrm{PB}, 211 /$.

Predlog + samostalnik + veznik + samostalnik

»...brez konca in kraja...«/SSS, 76/. »...z glavo in peto...«/JK, s. j., 308/. »Peter $z$ mesom in telesom...«/JK, s. j.,271/.»...sestavek brez nog in glave«/ DB, 189/. »...v petek in svetek«/CS, 141/.

Predlog + prislov + glagol

»Tako za malo se mu je zdelo...«/ PV, 160/. »...ga po strani zaničljivo pogleda«/JK, s. j., 319/. »...je hotel na dolgo in dobro popisovati...«/GR, 353/. »... na debelo prodajati...«/UB, $185 /$. 
Števnik + samostalnik + glagol

»...sedem cerkva govori...«/D, 240/. »...sedla $v$ dve gube ...«/G, 5, DB, 177 in GR, 300/.

Medmetni frazemi

»...ne bev ne mev...«/BT, 194, NV, 123 in D, 383/.»Bog daj, Bog daj!«/PB, 193/. »Bog daj dober dan...«/DB, 101/. ».. .bo cvenk in žvenk...«/DB, 187/. »Dobro jutro, Helena!«/HMS, 36, LP, 88 in PV, 152/.»...hvala Bogu...«/DB, 293, HMS, 32 in R, 41/. »Hvaljen bodi Jezus Kristus! «/KŽ, 49/. »Dober večer...«/KŽ, 21/.»Bog daj, Bog daj, dober večer«/DZ, 399, KŽ, 30/. »Vrag vedi...«/VSŽ in HMS, 40/.

\section{Religiozni frazemi}

Ti frazemi so poleg pridevniško-samostalniških najpogostejši. Navajam jih samo nekaj: »Vendar svet je poreden, odkar je Adam odkrhnil jabolko...«/D, 357/. »Ti si moj angel varuh«/DB, 241/. » (Polona) ...ni prinesla božjega blagoslova k hiši«/PV, 171, SKC, 272/. »...bo že Bog kaj dal«/SSS, 5/. »Bog jim daj svojo milost!« /SSS, 6/. »Bog moj, oče nebeški in ljuba Mati božja«/T, 123/. Z jedrno besedo »Bog« sem naštel okrog petdeset frazemov. »sodni dan«/DB, 187, VSŽ, 285/286/. »Pa za sedem naglavnih grehov« /PVNSP, 123/. »...devet naglavnih grehov«/KSVVG, 220/. »...kakor se bere iz svetega evangelija, da bo »en hlev in pastir «/SND, 146/147/. Več UBZ je iz molitve Očenaš. Pet frazemov je v PVNSP, 133/. “...zlodej (ima) spravljen poldeveto brazdo globoko zaklad”/SND, 134/. "Zlezi torej na deveto bukev"/POBK, 37/. “.. na beli dan ali v črno noč "/JK, s. j., 295/. Frazem beli dan je v D, 385, 407, T, 150, DB, 273, JK, s. j., 232,, 312, $\mathrm{R}, 56$ in KČ, 43/. S števniško komponento devet se vežejo jedrne besede dežela /OBKINH, 58, DZ, 313, KŽ, 55, 86, SS, 388 in LV, 81, 91/, dolina, JK, s. j., 264/, gora /DB, 216/, morje/JK, s.j.,230/, preteg/ŽVGD, 91/, prag/SSS, 20/ vas /D, $356 /$ in vrag /DIP, $82 /$.

\section{Primerjalni frazemi}

Največkrat se uporabljajo različne jedrne besede s primerjalni vezniki kakor, ko in kot. Z veznikom kakor sem naštel $26 \mathrm{UBZ}$, s ko 9 in s kot 1: “...spi kot polh" /R, 50/. Vseh primerjalnih frazemov je 54.

\section{Pregovori in reki}

V celotni Jurčičevi prozi sem naštel 62 pregovorov in rekov. Nekateri so tipično slovenski, slovanski, nekaj pa je nemških in latinskih. "Šola denar požira, kakor pravi pregovor"/SSS, 3/. "Klin se s klinom izbija, vino z vinom, glavo za glavo, tako pa tudi hudobnost s hudobnostjo" /DB, 165/166/. "Kdor laže, tudi krade" /DZ, 357/. "Wunder ist dises, dass die Crainerische Bauern sogar den Teuffel nicht forchten" /JNMSP, 207/. "Clara pacta, boni amici“/DZ, 394/. "Ubi bene, ibi patria"/DP, 250/. ...že obrabljen latinski pregovor veli: "in vino veritas"/VVK, 109/.

Frazeološki kalamburi

A res ni dosti manjkalo, da niste po vseh štirih lezli, ko bi bili sami, bili bi že 
ali po vseh štirih prišli kakor »biba leze, tovor nese...«/R, 44/. »...naš gospod ni človek, ki medveda precej pusti, ako ga za rep ne drži...«/JKo, 200/.

\section{Kletvice}

V celotni Jurčičevi prozi ne najdemo vulgarnih kletvic. Vseh kletvic je okrog dvajset, npr: "Bes jih dregni!" /R, 46/. "Pri mišji duši!" /T, 103/. "Devet hudičev!" /DZ, 418/. "In za pet hudirjev..." /T, 112, 118/. "Devet kosmatih vej ..." /SND, 141/. "Glej ga, jemlje te Kurent!”/R, 53/. “...naj se pes obesi...”/CS, 37, 92/. “...da bi te pasla sama kisla repa!"/R, 21/. "Brodnik pa kolne "svetca" in "majku mu..." /NKU, 284/. “...naj bi te zlomek vzel...!”/D, 432/.

\section{Frazemi iz Narodnih pravljic in pripovedk}

Navajam le tri klišeje, kot npr.: "Bratje so kuhali, pili in pojedali, meni pa niso nič dali" /NPIP, 81/. Konec pravljice se glasi: "Meni pa sta dala iz orehove lupine jesti, iz rešeta piti pa z lopato po riti" /NPIP, 67/. V JNMSP ima pisatelj Jurčič za uvod narodno uganko: "Jaz imam eno zver, /ki teče kot hudir, /ima dolge mustafe, pa hude zobe" /197/.

\section{Reminiscence}

"Ko bi bil vedel, da je mladenič bral veliko tistih romanov, ki jih šiba Cervantes v Don Kišotu..." /DB, 298/. "Prišel, videl, zmagal kakor Julij Cezar"/CS, 146/. "Če Dante pravi "da ni večje bolečine, kakor spominjati se srečnih dnij v nesreči”" /CS, 138/. "Si zopet tu , izgubljeni oven!" /JKo, 230/-citat je vzet iz evangelija (Mat., 18, 12; Luka, 15, 4-6). Po evangeliju je jedrna beseda ovca. V pripovedi DP navaja Jurčič verze iz Horacija: "Auream quisquis mediocritatem/ Diligt, tutut caret ob soleti/Sordibus tecti, caret invidenda" / Sobrius aula /253/. Prvo poglavje Jurija Kozjaka se začne z verzi S. Jenka iz pesmi Trojno gorje: "Gorje, kdor nima doma, /Kdor ni nikjer sam svoj gospod" /221/. V istem delu citira Jurčič Koseskega: "Mi čvrsti Slovenci smo, gremo na boj, / za pravdo, za dom, za cesarja..." /234/. Nekoliko pozneje srečamo v Juriju Kozjaku štirivrstično kitico iz Kraljedvorskega rokopisa: "Bilo klanje, bilo je mahanje, /žalovanje ino radovanje!..." /324/. V romanu DB naletimo na verze Lermontova: "Že truplo moje bo strohnelo, /in glej...pa kaj sem in kako, /to pač ne bo ljudi skrbelo" /388/. F. Levstika sta verza: "Saj polje več cvetic rodi, devic dežela več goji "/DB, 255/. Omenjen roman ima v 28. poglavju moto iz narodne pesmi. "Kdor pa hoče še peti, /mora od kraja začeti" /407/. V pripovedi MIP je kliše iz molitve Očenaš: "Ne vpelji nas v izkušnjavo" /75/. Sedmo poglavje JK, s. j. se začenja z drugo oktavo Prešernovega Krsta pri Savici, začetek 4. verza: "Potihnil ti vihar ni v prsih boja;/ le hujši se je zbudil črv nekdanji..." / 266/. Božidar Tirtelj pa je mislil s Prešernom: “ - da svoj čoln po sapi sreče, /komur sovražna je, zastonj obrača" /201//Slovo od mladosti, 1. verz 3.oktave/. V romanu Cvet in sad pripoveduje Krt Veselu Schillerjeve besede: "Prostora je v najmanjši koči za dva, ki se srčno ljubita" /183/.

\section{Elipsa}


npr.: “... prav nič se ni pomišljal, ne bele, ne črne ni rekel” /KŽ, 11/ - tu je izpust "besede". "Hlapec ga pride nekaj vprašat o delu, pa ne zve ne belega ne črnega..." /SS, 402/- tu je izpust “odgovora, ukaza, naročila...ipd. “...vsi odgovori (so) bob ob steno metani”/SS, 380/ - manjka prim. veznik kakor. "Ker mu ni bilo treba $v$ potu služiti kruha..."/UIB, 185/ - izpust svojega obraza. "Strela božja ga naj!" /HMS, 30/ - izpust zadene/ idr.

\section{Inverzija}

Inverziranih frazemov je malo (okrog petnajst). Navedimo le: "Šencana buša hrvaška..." /SND, 134/. "Dajte jo meni za dar božji” /DB, 322/. "To je očitna roka božja...”/Dv. B, 154/. “... je bil ravno v letih nerodnih brez vajeti...”/T, 93/. "Služba božja se prične " /SKC, 276, VVK, 112/. "...imela je lepo dušo, srce dobro..." /DB, 344/. “...srca nimaš za pol moža”/JK, s. j., 319/. “...pa če ni volja božja, grem pa prazen domov" /VSŽ, 312, KŽ, 68 in T, 103/...

\section{Substitucija}

“...stari Rojar...je pred sabo gledal samo lepo zeleno bodočnost” /GR, 388/, tj. svetlo. "Svetnike sem že videl in angel je, da so nagi namalani v kakovem altarju sedeli, komedijantov pa še ne, moj živ dan ne" /BT, 180/ - tu je substituiran povr. svoj.zaimek svoj. “...da sem zidal svoje gradove $v$ zrak" /DZ, 430/ - tu je substituiran samostalnik v mn. oblake. "Menda se ne bodo z glavo zaletovali ob kamen "/SKC, 264/- ob zid, steno. "...vsem vaščanom (je) delal zadnje hiše..." /CS, 229/, tj. krste. "No, no, Vrbanček, kaj te je hudoba obsedla, kajli?" /VSŽ, 286/, tj. vrag, hudič, hudir. "Pes jo vedi!" /HMS, 80/, tj. vrag, hudič, hudir. "Jezi ga pa...da mora od Petra do Pilata hoditi..." /CS, 84/- rel., tj. od Poncija do Pilata. - približno toliko substituiranih frazemov bi še lahko navedel.

Fonetične besede

Že uvodoma sem pojasnil, kaj je fonetična beseda. Nekaj jih navajam za ilustracijo, npr.: »za dlako...«/HMS, 71, DB, 279, JNMSP, 216/. »do dna«/DB, 211/. »črez glavo «/DvP, 263/. »do groba «/DB, 118/. »kar na hip«/HMS, 34/. »na lasu« /JK, s. j., 274, CS, 164, L, 3/. »pri luči«/POSG, 45. »mu ni bilo mar« /GR, 326/. »ko bi trenil«/GR, 376/. - Vseh fonetičnih besed je okrog dvajset.

Tavtološke frazeosheme

»Brat je brat«/JK, s. j., 240/. »dan na dan«/DvB, 151/ - samostalnik v im. + predlog na + isti sam. v tož. »od dne do dne«/SSS, 22/ - od + sam. v rod. + do + isti sam. v rod.. Ta frazeoshema je prisotna v SSS, 74, JK, s. j., 248, SKC, 268, SS, 375, 379, L, 3, IET, 230, NV, 137, HMS, 91, NV, 120, GR, 344, 395 in JKo, 223. »od hiše do hiše«/T, 153/ -od + sam. v rod. + do + isti sam. v rod. Enaka struktura je »od soseda do soseda«/IET, 244, ŽVGD, 89, NV, 141, D, 370 in DB, 112/, »od kmeta do kmeta, od bajte do bajte«/KŽ, 62/. »od leta do leta«/BT, 168, DvB, 153, G, 19/. »leto za letom« /JKo, 240/ - sam. v imen. + predl. + za + isti sam. v orod. »Mati je mati«/JKo, 210/ - sam. v im. + je +isti sam. v im. »od prve pike do zadnje pike«/DB, 270/-od + sam. v rod. + do + isti sam. v rod. »Hodil je od vasi 
do vasi, iz mesta $v$ mesto, iz kloštra $v$ klošter $/ \mathrm{POSG}, 47$ / - od + sam. v rod. + do + isti sam. $v$ rod.; iz + sam. $v$ rod. $+v+i$ isti sam. $v$ tož. »Nebesa so le nebesa, svet pa je le svet«/NPIP, 75/ - sam. v im. + so + isti sam. v im.; sam. + je + isti sam. v im. Po prikazanih strukturah sledijo tavtološke frazeosheme: »Oče so oče«/DvB, 146/, »iz oči $v$ oči« /L, 36, MIP, 79, VVK, 100, IET, 189, SND, 113, DB, 163/164, $225,238,300$, JK, s. j., 297, 303, BT, 182/, »Jaz bi mu tudi iz oči $v$ oči to povedal« /DB, 148/, »rama do rame«/T, 134/, »od roda do roda«/NPIP, 85, KSVVG, 210, $\mathrm{R}, 66 /$, »od rodu do rodu, od leta do leta«/NPIP, 96/, »iz rok $v$ roke«/DB, 179/, - iz + sam. $v$ rod. $+v+i s t i$ sam. $v$ tož. - ne navajam pa frazeoshem, ki so po strukturi enake zgoraj omenjenim.

\section{Statistična osvetlitev frazemov v Jurčičevi prozi}

Največ frazemov je v romanu Deseti brat (175), v pripovednem delu Domen in v povesti Jurij Kozjak po 88, v romanu Cvet in sad 79, v romanu Doktor Zober 56, v romanu Klošterski žolnir 74, v noveli Tihotapec 68, v pripovedi Grad Rojinje 49, v Sosedovem sinu 46, v povesti Rokovnjači (ne da bi jih nadaljeval Kersnik) 66, v Spominih starega Slovenca 77, v Hčeri mestnega sodnika 51, v Lepi Vidi 35, v zgodovinski povesti Ivan Erazem Tattenbach 27, v Sinu kmetiškega cesarja, v Spominih na deda 39, v Jesenski noči med slovenskimi polharji 28, v Nemškem valptu 23, v Lepi Vidi 22, v Božidarju Tirtlju 20, v povest Jurij Kobila 30, v noveli Dva brata 10, v Vojni krajini 10, v povesti Vrban Smukova ženitev 24, v povesti Pozimski večer na slovenski preji 15, v Pripovedki o beli kači 13; v povesti $\mathrm{O}$ bogatem kmetu in njegovi hčeri 9, v Kozlovski sodbi v Višnji gori 7, v noveli Dva prijatelja $6 \ldots$ Vseh frazemov v prozi Josipa Jurčiča je 1501, kar je manj kot v prozi Janka Kersnika (1849). Če upoštevamo Jurčičevo kratko življenjsko obdobje in dela, ki jih je napisal, je treba reči, da je frazeologija zelo bogata. Prevladujejo frazemi iz ljudskega jezika, stilno označenih je dokaj malo. Pri štetju frazemov sem izpustil nekaj reminiscenc. Ne glede na to pa daje pričujoč zapis okvirno sliko Jurčičeve frazeologije.

\section{Seznam kratic}

BR, BD - Bela ruta, bel denar

BUSK - Berač Urh s Kostela

BST - Bojim se te

BT - Božidar Tirtelj

BIL - Brat in ljubi

CS - Cvet in sad

ČIŽPA - Črta iz življenja političnega agitatorja

DIP - Deklica in pesoglavci

DB - Deseti brat

DZ - Doktor Zober

D - Domen

DvB - Dva brata

DvP - Dva prijatelja

G - Golida 
GR - Grad Rojinje

HMS - Hči mestnega sodnika

IET - Ivan Erazem Tattenbach

JNMSP - Jesensko noč med slovenskimi polharji

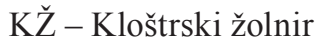

JKo - Jurij Kobila

JK, s. j., Jurij Kozjak, slovenski janičar

KJKPPD - Kako je Kotarjev Peter pokoro delal

KSKC - Kosoman, sin kmetiškega cesarja

KSVVG - Kozlovska sodba v Višnji gori

KPS - Kres pri Slovencih

LV - Lepa Vida

$\mathrm{L}$-Lipe

MIP - Moč in pravica

NKU - Na kolpskem ustju

NPIP - Narodne pravljice in pripovedke

NV - Nemški valpet

NPS - Nepovabljen svat

$\mathrm{OA}$ - $\mathrm{O}$ angelu

OAA - Obri ali Avari

ON - O nadlogi

$\mathrm{OR}-\mathrm{O}$ rojenicah

OBKINH - O bogatem kmetu in njegovi hčeri

PT - Pipa tobaka

PB - Ponarejeni bankovci

PVNSP - Pozimski večer na slovenski preji

POBK - Pripovedka o beli kači

PV - Prazna vera

POSG - Pripovedka o sv. Gregorju

$\mathrm{R}$ - Rokovnjači

SKC - Sin kmetiškega cesarja

SNPIP - Slovenske narodne pripovedi in pravljice

SS - Sosedov sin

SND - Spomini na deda

SSS - Spomini starega Slovenca

$\mathrm{SV}$ - Stari vojščak

TP - Telečja pečenka

$\mathrm{T}$ - Tihotapec

UIB - Uboštvo in bogastvo

VSŽ - Vrban Smukova ženitev

VVK - V Vojni krajini

ZVGIRŽ - Zakrpana Višnja gora in raztrgan Žužemberk

ZŽ - Zmenjena Ženitev

ŽVGD - Županovanje v Globokem dolu 
Josipa Jurčiča Zbrani spisi, Uredil Fran Levec, 11 zv., Ljubljana 1882-1892.

Josip Jurčič, Izbrano delo, I. in IV. knjiga, Ljubljana 1974, uredniški odbor: Josip Vidmar, dr. Franc Zadravec, Franček Bohanec, dr. Janko Kos.

\section{Literatura}

A. M. Babkin, Russkaja frazeologija, ee pazvitie i istočniki, Leningrad 1970. Etbin Bojc, Pregovori in reki na reki na Slovenskem, DZS, Ljubljana 1980. Frazeologičeskij slovar ' russkogo jazyka pod redakciej A. I. Molotkova, Moskva 1967.

Janez Keber, Frazeološki slovar slovenskega jezika, Poskusni zvezek, Ljubljana 2003.

Antica Menac, Neka pitanja u vezi s klasifikacijom frazeologije, Filologija, št. 8, Zagreb 1978, str. 221.

Antica Menac, Hrvatska frazeologija, Knjigra, Zagreb, svibanj, 2007, str. 42.

Milenko Popović, O frazemu i zamenljivosti njegovih elemenata, Iz frazeološke problematike, Zagreb 1980, str. 48.

L. I. Rojzenzon, Lekcii po obščej i russkoj frazeologii, Učebnoe posobie, Samarkand 1973.

Russko-horvatskij ili serbskij frazeologičeskij slovar' pod redakciej Anticy Menac, Zagreb 1979-2980 (Me).

N. M. Šanskij, Frazeologija sovremennogo russkogo jazyka, Izd-vo Vysšaja škola, Moskva 1969, Izdanie 2-e, ispravlennoe i dopolnennoe.

V. P. Žukov, Semantika frazeologičeskih oborotov, Moskva »Prosveščenie«, 1978.

\section{Фразеология в прозаических произведениях Йосипа Юрчича}

\section{Резюме}

До сих пор никто не исследовал фразеологии в прозаических произведениях словенского писателя Йосипа Юрчича. Минимальной фразеологической ендиницей является фонетическое слово, т. е. одно полнозначное слово под ударением, на которое наслоняются энклитики и проклитики. Так понимают ФЕ (фразеологическая единица) фразеологи Л. И. Ройзензон и А. Менаи, основоположник загребской фразеологической школь.

Более всего в прозе Й. Юрчича фраземов с опорным словом существительное + глагол, напр.: »Vidite, da sem držal besedo?»/Josip Jurčič, ZS, II. ZV., DZ, 347/. На втором месте, учитывая частотность, являются УСК со структурой прилагательное + существительноею. Эти УСК я зарегистрировал 110 раз, 
Hanp. : "Oni teden bo polna luna«/J. Jurčič, ZS, I.zv. / Uboštvo in bogastvo, 180/. Одинаковое число также религиозных фраземов, напр: »Ti si moj angel varuh »/J. Jurс̌ič, ZS, III. ZV, DB, 241/. Между фразеологическими соматизмами наиболее часто выступают УСК с опорным словом глаза : »...je povzdignila oči »/J. Jurčič, ZS, IV. ZV, HMS, 36/.

Центральное место исследования занимает глагольная фразеология. Внимание уделяю также фольклорным и сравнительным фраземам; 6 анализ включаю пословищы и поговорки, ругательства, каламбуры, загадки, реминисиенции, эллипсис, субституции, фонетические слова и тавтологические фразеосхемы.

В статье показываем самые разные словесные структуры, учитывая части речи. В прозаических произведениях Йосипа Юрчича около тысячи пятиста УСК. Йурчич применяет народную фразеологию. Очень маленькое число фраземов с стилистическими пометами.

Jurij Emanuel Rojs

Gregorčičeva 1b, 2000 Maribor

Jurij.Rojs@triera.net 